\title{
1 Supplementary Material for Denitrification in soil as a 2 function of oxygen supply and demand at the microscale
}

\author{
3 Lena Rohe ${ }^{1}$, Bernd Apelt ${ }^{1}$, Hans-Jörg Vogel ${ }^{1}$, Reinhard Well ${ }^{2}$, Gi-Mick Wu ${ }^{3}$, Steffen Schlüter ${ }^{1}$ \\ $4 \quad{ }^{1}$ Helmholtz Centre for Environmental Research - UFZ, Department Soil System Sciences, Theodor-Lieser-5 Str. 4, \\ 506120 Halle, Germany \\ $6 \quad{ }^{2}$ Thünen Institute of Climate Smart Agriculture, Bundesallee 65, 38116 Braunschweig, Germany \\ $7 \quad{ }^{3}$ Helmholtz Centre for Environmental Research - UFZ, PACE, Permoserstraße 15, 04318 Leipzig, Germany \\ 8 Correspondence to: Lena Rohe, (lena.rohe@ufz.de)

10 Detailed information on pre-incubation, determination of water holding capacity and 11 experimental set-up (Section 2: Material and Methods, 1. Incubation)

12 For pre-incubation the soil was loosely placed on a tray, adjusted to $50 \%$ water holding capacity 13 (WHC) with a spray can and stored at room temperature in the dark for two weeks.

14 Additional soil cores with the same dimension were packed in an identical manner as described in the 15 Material and Method section and fully saturated by immersion in a water bath for $24 \mathrm{~h}$. The water-holding 16 capacity (v/v \% WHC) for each soil material was determined after free drainage. These water volumes 17 were taken as a reference to adjust the above-mentioned saturation levels (70, 83 and 95\% WHC). Note 18 that WHC values are not identical to water saturations expressed in $\mathrm{v} / \mathrm{v} \%$ water-filled pore space (WFPS), 19 since $100 \%$ WHC covers a smaller volume than the total pore volume due to 1) air entrapment during full 20 immersion in water and 2) drainage of the biggest pores in a pressure head range of -10 to $0 \mathrm{~cm}$ in a $10 \mathrm{~cm}$ 21 tall, freely draining sample.

22 The cylindrical PVC columns containing the packed soil aggregates $\left(698.41 \mathrm{~cm}^{3}\right)$ were closed tightly 23 by sealing caps at the top and bottom. The closed column was equipped with an in- and outlet to allow 24 flushing the headspace $\left(69.83 \mathrm{~cm}^{3}\right)$ through steel capillaries (total volume $1.33 \mathrm{~cm}^{3}$ ). A maximal 25 evaporation loss during incubation of one soil core is estimated to be around $1.22 \mathrm{~g} \mathrm{H}_{2} \mathrm{O}$. A temperature 26 sensor (PT100) was installed through the centre of the lid reaching the repacked aggregates with a depth 27 of ca $3 \mathrm{~cm}$ down to assure constant temperature of $20^{\circ} \mathrm{C}$ during incubation. 
28 Table with average data for each treatment (WFPS and aggregate size) with average values of $\mathrm{CO}_{2}, \mathrm{~N}_{2} \mathrm{O}$ and $\left(\mathrm{N}_{2} \mathrm{O}+\mathrm{N}_{2}\right)$ fluxes, $\mathrm{O}_{2}$ 29 saturation, total porosity, visible air content $\left(\varepsilon_{v i s}\right)$, connected air content $\left(\varepsilon_{c o n}\right)$, anaerobic soil volume fraction (ansvf), simulated 30 diffusivity $\left(D_{\text {sim }}\right)$ and product ratio (pr) for soil from Gießen (GI) and Rotthalmünster (RM)

Table S1: Average values for $\mathrm{CO}_{2}, \mathrm{~N}_{2} \mathrm{O}$ and $\left(\mathrm{N}_{2} \mathrm{O}+\mathrm{N}_{2}\right)$ fluxes, $\mathrm{O}_{2}$ saturation, visible air content $\left(\varepsilon_{\mathrm{vis}}\right)$, connected air content ( $\left.\varepsilon_{\text {con }}\right)$, anaerobic soil volume fraction (ansvf), simulated diffusivity $\left(D_{\text {sim }}\right)$ and product ratio $(p r)\left[\mathrm{N}_{2} \mathrm{O} /\left(\mathrm{N}_{2} \mathrm{O}+\mathrm{N}_{2}\right)\right]$. Standard error $(\mathrm{n}=3)$ is shown in the brackets.

\begin{tabular}{|c|c|c|c|c|c|c|c|c|c|c|c|c|}
\hline soil & $\begin{array}{c}\text { WFPS } \\
{[\%]}\end{array}$ & $\begin{array}{c}\text { Aggre- } \\
\text { gate } \\
\text { size } \\
{[\mathrm{mm}]}\end{array}$ & $\begin{array}{c}\mathrm{CO}_{2}-\mathrm{C} \\
{\left[\mu \mathrm{g} \mathrm{h}^{-1} \mathrm{~kg}^{-1}\right]}\end{array}$ & $\begin{array}{c}\mathrm{N}_{2} \mathrm{O}-\mathrm{N} \\
{\left[\mu \mathrm{g} \mathrm{h} \mathbf{h}^{-1} \mathrm{~kg}^{-1}\right]}\end{array}$ & $\begin{array}{l}\left(\mathrm{N}_{2} \mathrm{O}+\mathrm{N}_{2}\right)-\mathrm{N} \\
{\left[\mu \mathrm{g} \mathrm{h}^{-1} \mathrm{~kg}^{-1}\right]}\end{array}$ & $\begin{array}{c}\mathrm{O}_{2} \\
{[\% \text { air }} \\
\text { saturation] }\end{array}$ & $\begin{array}{c}\text { Total } \\
\text { porosity } \\
{[-]}\end{array}$ & $\begin{array}{l}\varepsilon_{v i s} \\
{[-]} \\
\end{array}$ & $\begin{array}{c}\varepsilon_{\text {con }} \\
{[-]}\end{array}$ & $\begin{array}{c}\text { ansvf } \\
{[-]}\end{array}$ & $\begin{array}{c}D_{\text {sim }} \\
{\left[\mathbf{m}^{2} \mathbf{s}^{-1}\right]}\end{array}$ & $p r[-]$ \\
\hline GI & 63 & $2-4$ & $\begin{array}{l}23.53 \\
(0.77)\end{array}$ & $\begin{array}{c}0.01 \\
(<0.01)\end{array}$ & $0.13(0.08)$ & $47.99(1.30)$ & $\begin{array}{c}0.21 \\
(0.03)\end{array}$ & $\begin{array}{c}0.21 \\
(0.03)\end{array}$ & $\begin{array}{c}0.20 \\
(0.03)\end{array}$ & $\begin{array}{c}<0.01 \\
(<0.01)\end{array}$ & $\begin{array}{c}1.0910^{-06} \\
\left(1.8210^{-08}\right)\end{array}$ & $\begin{array}{c}0.34 \\
(0.16)\end{array}$ \\
\hline GI & 63 & $4-8$ & $\begin{array}{l}22.10 \\
(0.66)\end{array}$ & $\begin{array}{c}0.06 \\
(0.01)\end{array}$ & $0.13(0.02)$ & $55.69(1.87)$ & $\begin{array}{c}0.20 \\
(0.02)\end{array}$ & $\begin{array}{c}0.20 \\
(0.02)\end{array}$ & $\begin{array}{c}0.20 \\
(0.02)\end{array}$ & $\begin{array}{c}<0.01 \\
(<0.01)\end{array}$ & $\begin{array}{c}1.0810^{-06} \\
\left(1.5610^{-08}\right)\end{array}$ & $\begin{array}{c}0.44 \\
(0.09)\end{array}$ \\
\hline GI & 75 & $2-4$ & $\begin{array}{l}27.12 \\
(0.65)\end{array}$ & $\begin{array}{c}0.79 \\
(0.11)\end{array}$ & $1.56(0.09)$ & $56.48(2.50)$ & $\begin{array}{c}0.18 \\
(0.03)\end{array}$ & $\begin{array}{c}0.13 \\
(0.03)\end{array}$ & $\begin{array}{c}0.12 \\
(0.03)\end{array}$ & $\begin{array}{c}0.04 \\
(0.02)\end{array}$ & $\begin{array}{c}1.5910^{-08} \\
\left(7.2610^{-09}\right)\end{array}$ & $\begin{array}{c}0.52 \\
(0.08)\end{array}$ \\
\hline GI & 75 & $4-8$ & $\begin{array}{l}24.10 \\
(0.59)\end{array}$ & $\begin{array}{c}0.79 \\
(0.12)\end{array}$ & $1.18(0.19)$ & $61.78(2.22)$ & $\begin{array}{c}0.19 \\
(0.03) \\
\end{array}$ & $\begin{array}{c}0.14 \\
(0.03)\end{array}$ & $\begin{array}{c}0.11 \\
(0.04)\end{array}$ & $\begin{array}{c}0.21 \\
(0.07)\end{array}$ & $\begin{array}{r}2.7610^{-09} \\
\left(2.3210^{-09}\right)\end{array}$ & $\begin{array}{c}0.68 \\
(0.06) \\
\end{array}$ \\
\hline GI & 85 & $2-4$ & $\begin{array}{c}7.70 \\
(0.59)\end{array}$ & $\begin{array}{c}0.82 \\
(0.11)\end{array}$ & $1.20(0.28)$ & $33.77(1.47)$ & $\begin{array}{c}0.18 \\
(0.03)\end{array}$ & $\begin{array}{c}0.12 \\
(0.02)\end{array}$ & $\begin{array}{c}0.03 \\
(0.03)\end{array}$ & $\begin{array}{c}0.79 \\
(0.14)\end{array}$ & $\begin{array}{r}5.5910^{-10} \\
\left(3.3610^{-10}\right)\end{array}$ & $\begin{array}{c}0.64 \\
(0.09)\end{array}$ \\
\hline GI & 85 & $4-8$ & $\begin{array}{c}5.52 \\
(0.52) \\
\end{array}$ & $\begin{array}{c}0.58 \\
(0.11) \\
\end{array}$ & $0.94(0.09)$ & $39.89(2.55)$ & $\begin{array}{c}0.20 \\
(0.03)\end{array}$ & $\begin{array}{c}0.10 \\
(0.02)\end{array}$ & $\begin{array}{c}0.01 \\
(0.02)\end{array}$ & $\begin{array}{c}0.80 \\
(0.09)\end{array}$ & $\begin{array}{r}2.0010^{-10} \\
\left(4.0010^{-11}\right)\end{array}$ & $\begin{array}{c}0.60 \\
(0.10)\end{array}$ \\
\hline $\mathrm{RM}$ & 65 & $2-4$ & $\begin{array}{c}6.36 \\
(0.10) \\
\end{array}$ & $\begin{array}{c}<0.01 \\
(<0.01)\end{array}$ & NA & $55.11(2.20)$ & $\begin{array}{c}0.16 \\
(0.03) \\
\end{array}$ & $\begin{array}{c}0.16 \\
(0.03)\end{array}$ & $\begin{array}{c}0.15 \\
(0.03)\end{array}$ & $\begin{array}{c}<0.01 \\
(<0.01)\end{array}$ & $\begin{array}{r}2.2410^{-07} \\
\left(1.3910^{-08}\right)\end{array}$ & n.d. \\
\hline $\mathrm{RM}$ & 65 & $4-8$ & $\begin{array}{c}6.94 \\
(0,12)\end{array}$ & $\begin{array}{c}<0.01 \\
(<0.01)\end{array}$ & $0.03(0.02)$ & $48.95(2.56)$ & $\begin{array}{c}0.15 \\
(0.03) \\
\end{array}$ & $\begin{array}{c}0.15 \\
(0.03) \\
\end{array}$ & $\begin{array}{c}0.15 \\
(0.03)\end{array}$ & $\begin{array}{c}<0.01 \\
(<0.01)\end{array}$ & $\begin{array}{r}2.0810^{-07} \\
\left(2.6910^{-08}\right)\end{array}$ & $\begin{array}{c}0.08 \\
(0.04)\end{array}$ \\
\hline $\mathrm{RM}$ & 78 & $2-4$ & $\begin{array}{c}7.66 \\
(0.18)\end{array}$ & $\begin{array}{c}0.19 \\
(0.02)\end{array}$ & $0.30(0.14)$ & $59.16(2.88)$ & $\begin{array}{c}0.14 \\
(0.03)\end{array}$ & $\begin{array}{c}0.10 \\
(0.03)\end{array}$ & $\begin{array}{c}0.09 \\
(0.03)\end{array}$ & $\begin{array}{c}0.08 \\
(0.06)\end{array}$ & $\begin{array}{r}1.0310^{-08} \\
\left(3.6510^{-09}\right)\end{array}$ & $\begin{array}{c}0.65 \\
(0.08)\end{array}$ \\
\hline $\mathrm{RM}$ & 78 & $4-8$ & $\begin{array}{c}6.27 \\
(0.15)\end{array}$ & $\begin{array}{c}0.26 \\
(0.04)\end{array}$ & $0.43(0.08)$ & $53.41(2.60)$ & $\begin{array}{c}0.14 \\
(0.03)\end{array}$ & $\begin{array}{c}0.10 \\
(0.03)\end{array}$ & $\begin{array}{c}0.07 \\
(0.04)\end{array}$ & $\begin{array}{c}0.34 \\
(0.22)\end{array}$ & $\begin{array}{c}1.4710^{-08} \\
\left(7.3410^{-09}\right)\end{array}$ & $\begin{array}{c}0.61 \\
(0.05)\end{array}$ \\
\hline $\mathrm{RM}$ & 88 & $2-4$ & $\begin{array}{c}2.22 \\
(0.04)\end{array}$ & $\begin{array}{c}0.22 \\
(0.01)\end{array}$ & $0.37(0.11)$ & $22.61(1.95)$ & $\begin{array}{c}0.10 \\
(0.02)\end{array}$ & $\begin{array}{c}0.06 \\
(0.02)\end{array}$ & $\begin{array}{c}0.03 \\
(0.02)\end{array}$ & $\begin{array}{c}0.69 \\
(0.10)\end{array}$ & $\begin{array}{c}3.2710^{-11} \\
\left(2.0210^{-11}\right)\end{array}$ & $\begin{array}{c}0.64 \\
(0.06)\end{array}$ \\
\hline $\mathrm{RM}$ & 88 & $4-8$ & $\begin{array}{c}2.06 \\
(0.05)\end{array}$ & $\begin{array}{c}0.25 \\
(0.02)\end{array}$ & $0.37(0.08)$ & $42.01(2.59)$ & $\begin{array}{c}0.13 \\
(0.03)\end{array}$ & $\begin{array}{c}0.07 \\
(0.02)\end{array}$ & $\begin{array}{c}0.02 \\
(0.01)\end{array}$ & $\begin{array}{c}0.74 \\
(0.07)\end{array}$ & $\begin{array}{c}2.0310^{-09} \\
\left(1.7610^{-09}\right)\end{array}$ & $\begin{array}{c}0.67 \\
(0.04)\end{array}$ \\
\hline
\end{tabular}

n.d.: not detectable; NA: not applicable 
$\mathrm{N}_{2} \mathrm{O}$ and $\mathrm{CO}_{2}$ fluxes (Figure $\mathrm{S} 1$ ) and $\mathrm{O}_{2}$ saturation at 7 locations within the soil core (Figure $\mathrm{S} 2$ ) were measured during the incubation time of approximately 192h. In the beginning of incubation establishment of equilibrium was assumed and therefore $24 \mathrm{~h}$ of measurements in the beginning of the incubation time were excluded.
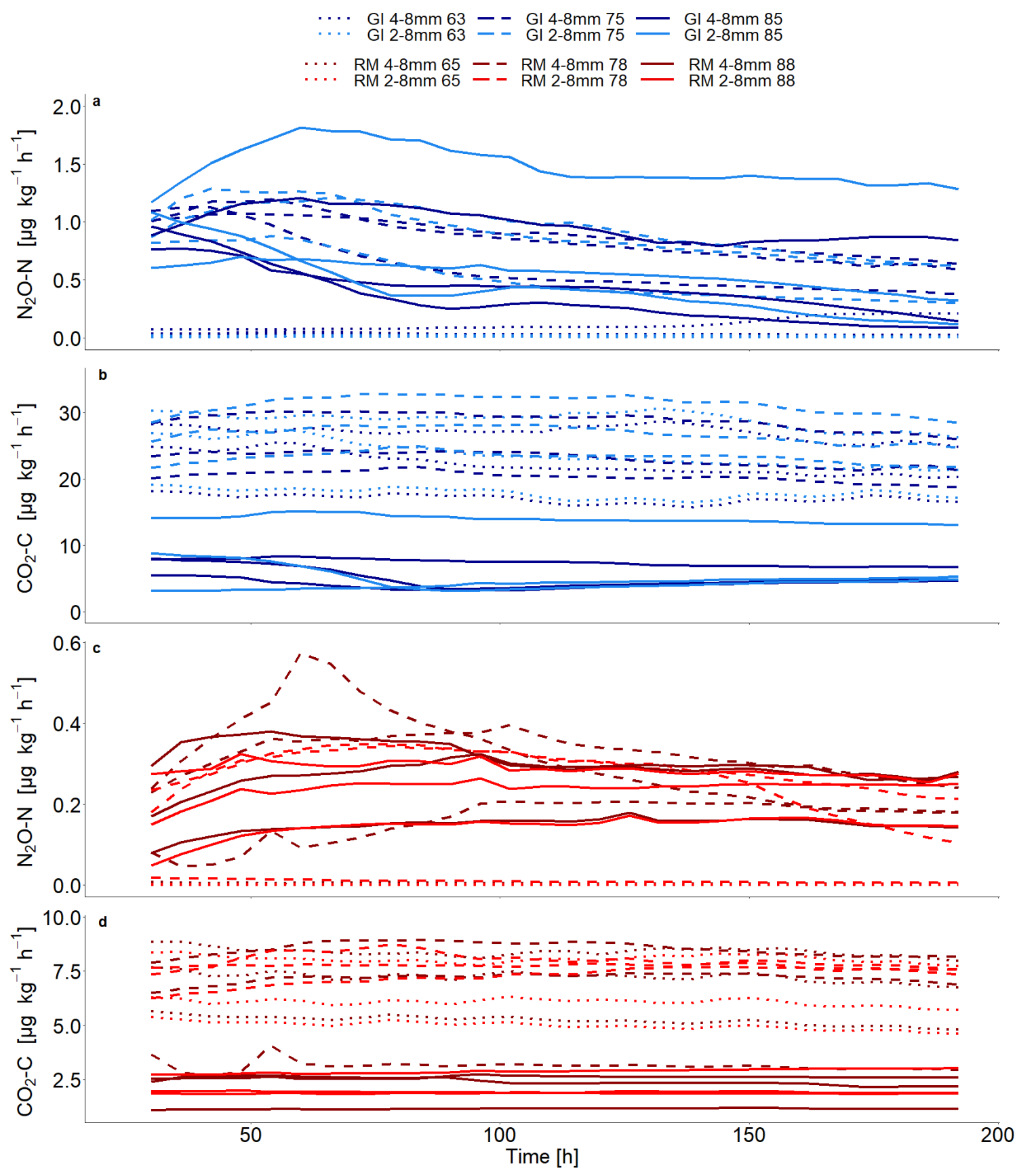

Figure S1: Average $\mathrm{N}_{2} \mathrm{O}$ and $\mathrm{CO}_{2}$ fluxes as a function of incubation time for soil from Rotthalmünster (RM) in red and Gießen (GI) in blue, two aggregate sizes (2-4 and 4-8 $\mathrm{mm}$ ) and three water saturations (dotted, dashed or solid line depicted lowest, medium and highest water saturation, respectively) with three replicates. 


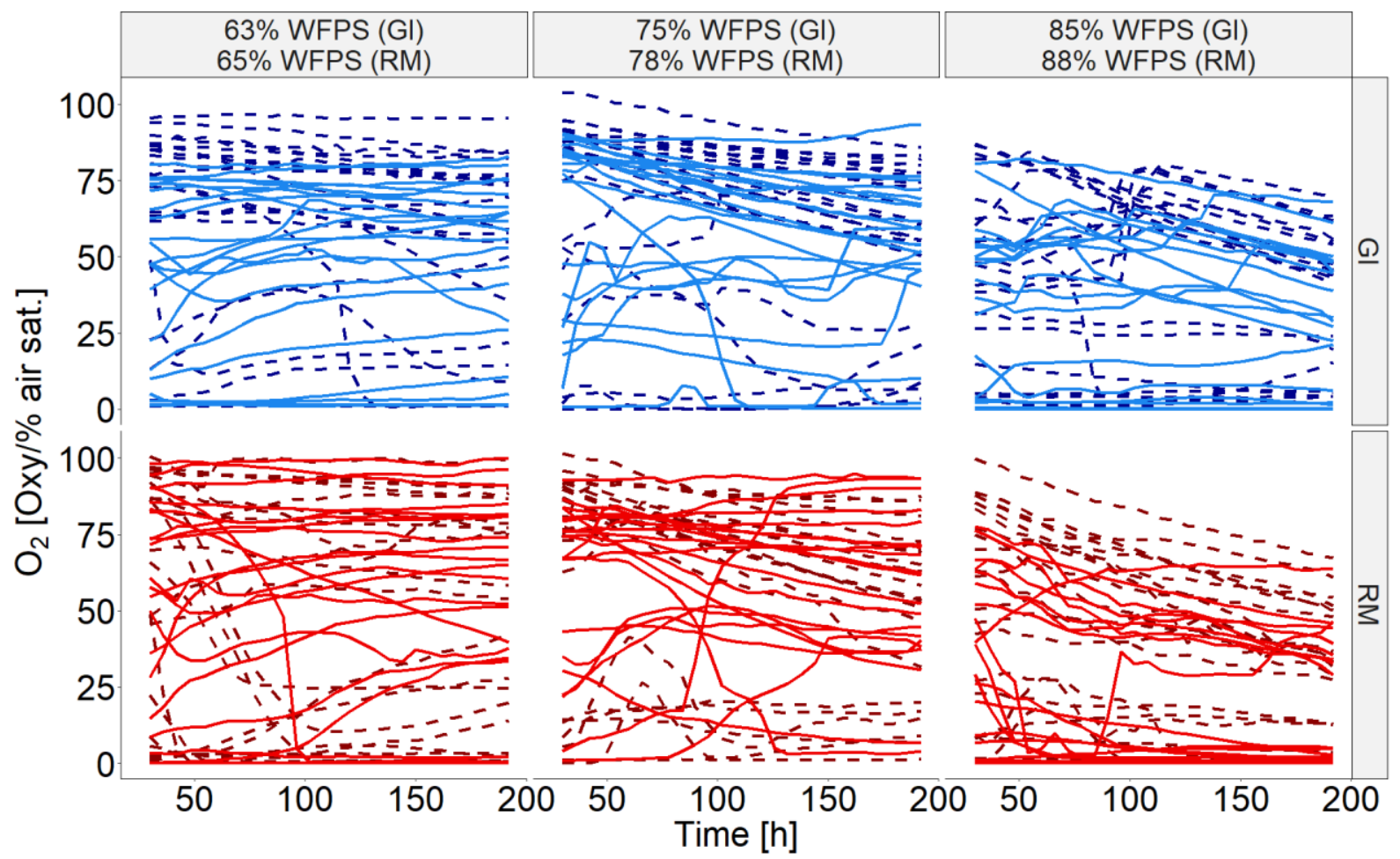

Figure S2: Average $\mathrm{O}_{2}$ saturations measured by 7 sensors per soil core as a function of incubation time for soil from Rotthalmünster (RM) in red and Gießen (GI) in blue, two aggregate sizes (2-4 and 4-8 mm (solid and dashed lines, respectively)) and three water saturations with three replicates each.

Detailed description of calculating different pools for ${ }^{15} \mathrm{~N}$

The fraction of $\mathrm{N}$ in $\mathrm{N}_{2} \mathrm{O}\left(f_{p \_} N_{2} \mathrm{O}\right)$ or $\mathrm{N}_{2}\left(f_{p \_} N_{2}\right)$ originating from ${ }^{15} \mathrm{~N}$-labelled $\mathrm{NO}_{3}{ }^{-}$pool within one sample was calculated according to (Spott et al., 2006; Lewicka-Szczebak et al., 2013; Well et al., 2019) using the ${ }^{15} \mathrm{~N}$ abundance of $\mathrm{N}_{2}$ or $\mathrm{N}_{2} \mathrm{O}$ measured in the analyzed gas sample $\left(a_{m}\right)$, in the non-labelled $\mathrm{N}_{2}$ in technical gas $\left(a_{b g d}\right)$, and the calculated ${ }^{15} \mathrm{~N}$ abundance of the active $\mathrm{NO}_{3}{ }^{-}$pool $\left(a_{p}\right)$.

$f_{p_{-}} N_{2} O=\frac{a_{m}-a_{b g d}}{a_{p}-a_{b g d}}$

$f_{p-} N_{2}=\frac{a_{m}-a_{b g d}}{a_{p}-a_{b g d}}$

56 with

$57 \quad a_{m}=\frac{{ }^{29} R+2^{30} R}{2\left(1+{ }^{29} R+{ }^{30} R\right)}$

58 and using the fraction of ${ }^{30} \mathrm{~N}_{2}$ in the gas sample $\left({ }^{30} \chi_{\mathrm{m}}\right)$ :

$59 a_{p}=\frac{{ }^{30} \chi_{m}-a_{m} \cdot a_{b g d}}{a_{m}-a_{b g d}}$

60 This is based on the a non-random distribution of isotopes in $\mathrm{N}_{2} \mathrm{O}$ and $\mathrm{N}_{2}$ (Spott et al., 2006):

61

${ }^{30} \chi_{m}=\frac{{ }^{30} R}{1+{ }^{29} R+{ }^{30} R}$ 
62 Thus, with $f_{p \_} \mathrm{N}_{2} \mathrm{O}$ the $\mathrm{N}_{2} \mathrm{O}$ flux from denitrification $\left(\mathrm{N}_{2} \mathrm{O} \_\right.$deni) was calculated

$63 \mathrm{~N}_{2} \mathrm{O} \_$deni $=\mathrm{N}_{2} \mathrm{O}_{-}$total $* f_{p \_} \mathrm{N}_{2} \mathrm{O}$

64 The $\mathrm{f}_{\mathrm{p} \_} \mathrm{N}_{2} \mathrm{O}$ was constantly near 1 for both soils, aggregate sizes, water saturations and time points of 65 sampling resulting in very similar $\mathrm{N}_{2} \mathrm{O} \_$total and $\mathrm{N}_{2} \mathrm{O}$ _deni values (Figure S3). The time resolution for $66 \mathrm{~N}_{2} \mathrm{O}$ _total was much higher than for isotopic analysis and therefore $\mathrm{N}_{2} \mathrm{O}$ _total was used to calculate $\mathrm{N}_{2} \mathrm{O}$ 67 fluxes from denitrification and for statistical analysis.

68

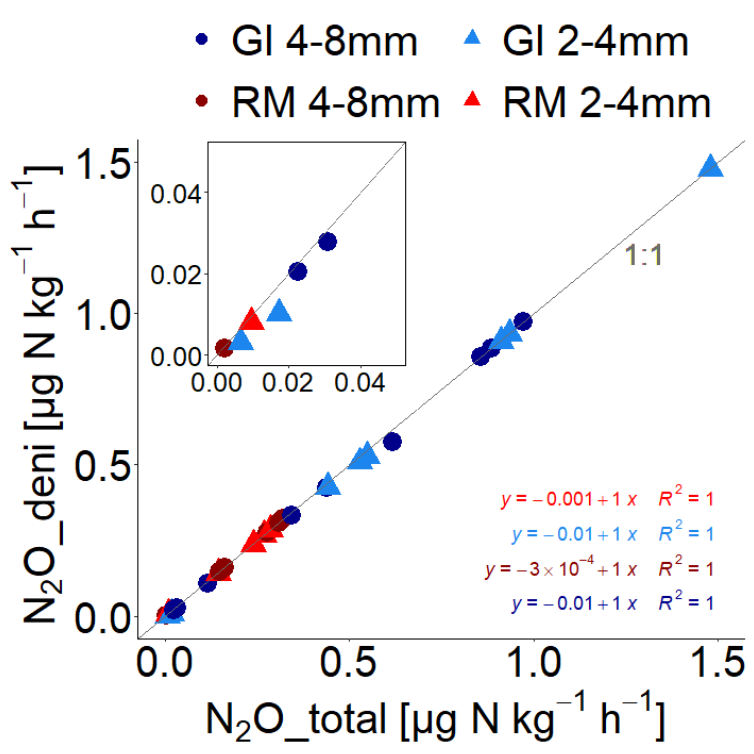

Figure S3: Comparison of total $\mathrm{N}_{2} \mathrm{O}$ emissions $\left(\mathrm{N}_{2} \mathrm{O}\right.$ _total) captured by gas chromatography and $\mathrm{N}_{2} \mathrm{O}$ emissions from denitrification ( $\left.\mathrm{N}_{2} \mathrm{O} \_d e n i\right)$ from experimental treatments with soil from Rotthalmünster (RM) and Gießen (GI), two aggregate sizes (2-4 and 4-8 mm) and three water saturations. Goodness of fit to the 1:1 line (gray line) is expressed as slope and $\mathbf{R}^{2}$ from linear regression. 


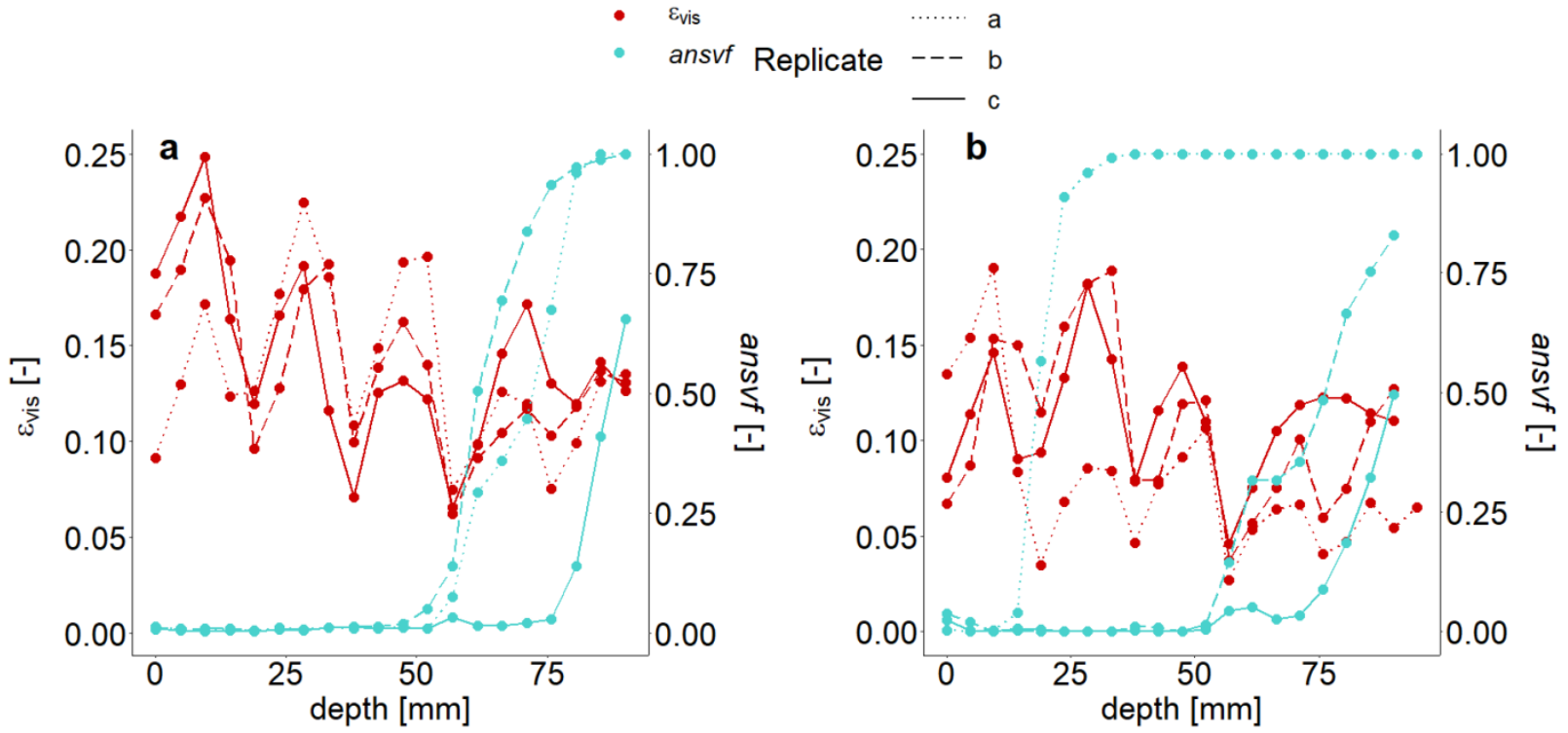

Figure S4: Visible air content $\left(\varepsilon_{\text {vis }}\right)$ and the anaerobic soil volume fraction (ansvf) as a function of soil core depth for soil from (a) Gießen (GI) and (b) Rotthalmünster (RM). Shown here are examples of 3 replicates of repacked soil cores with aggregates of $4-8 \mathrm{~mm}$ size incubated at medium water saturation of $75 \%$ with GI and $78 \%$ with RM soil. Values shown here for air content and anaerobic soil volume fraction are aggregated for $4.7 \mathrm{~mm}$ segments in depth.

Two representative examples of one treatment were chosen to illustrate the impact of packing the soil on visible air content $\left(\varepsilon_{v i s}\right)$ and anaerobic soil volume fraction (ansvf) (large aggregates of GI soil incubated at 75\% WFPS and large aggregates of RM soil incubated at $78 \%$ WFPS) (Figure S4). During the packing procedure, intervals of $2 \mathrm{~cm}$ were the best option to adjust the target material-specific bulk densities and water saturations within the soil core. The average $\varepsilon_{v i s}$ did not differ between replicates of one treatment (Figure 4), but decreased with increasing depth of the packed soil core and was extremely reduced at the top of one packing interval (Figure S4). This varying compaction in different layers affected also the ansvf of each repacked core (Figure S4). The ansvf dramatically increased in layers, where lowest $\varepsilon_{v i s}$ was observed. In some cases, the ansvf even reached 1, i.e. complete exclusion from connected air-filled pores.

Diffusivity was simulated for individual aggregates as well as for the entire soil core (bulk diffusivity) directly on segmented X-ray CT data on a workstation with Intel® Xeon® CPUs (E7-8867v4, 2.46Hz, 36 
Software (Math2Market GmbH, Kaiserslautern, Germany). A hierarchical approach was used to estimate the effective diffusivity of the wet soil matrix by simulating Laplace diffusion on cubes contained in individual soil aggregates with the Explicit Jump solver assuming free diffusion in the visible pore space,

100 a completely impermeable background and symmetric boundary condition on all sides (Wiegmann and

101 Zemitis, 2006; Wiegmann and Bube, 2000). The resulting effective diffusion coefficient is expressed as a

102 percentage of the diffusion coefficient in the free fluid and was in the range of $6.610^{-4} \pm 3.710^{-4} \%$ and 2.4

$10310^{-2} \pm 1.310^{-2} \%$ for wet aggregates of RM and GI soil, respectively. For the soil cores with $<70 \%$ WFPS

104 the visible pore space in the high-resolution aggregate images is assumed to be air-filled, whereas for soil

105 cores with $\geq 75 \%$ WFPS it is assumed to be water-filled, which is justified by the fact that 1) the air-filled

106 porosity at <70\% WFPS in individual aggregates (RM: 17.6\%, GI: $23.1 \%$ ) exceeds the visible pore space

107 in low-resolution soil core images (RM: $15.8 \%$, GI: 20.6\%) and 2) that in contrast to the higher moisture

108 levels no free water could be identified at the column scale with air-filled porosity at $<70 \%$ WFPS. Thus,

109 the effective diffusion coefficient for soil matrix is determined with respect to the oxygen diffusion

110 coefficient $\left(\mathrm{D}_{\mathrm{O} 2}\right)$ at $2 \% \mathrm{O}_{2}$ in pure air $\left(2.0310^{-5} \mathrm{~m}^{2} \mathrm{~s}^{-1}\right)$ and in pure water $\left(1.9710^{-9} \mathrm{~m}^{2} \mathrm{~s}^{-1}\right)$ at $20^{\circ} \mathrm{C}$,

111 respectively (http://compost.css.cornell.edu/oxygen/oxygen.diff.air.html).

112 Another series of diffusion experiments was modeled with the Explicit Jump solver on the entire soil 113 cores (1550x1550x [1500-1600] voxels) with the effective diffusion coefficient of the soil matrix taken

114 from aggregate simulations, an impermeable exterior, impermeable mineral grains (GI only) and the

115 diffusion coefficient of oxygen in air and water ( $\geq 70 \%$ WFPS only) in the respective material classes. In

116 order to save memory, periodic boundary conditions were assumed on all sides. This is irrelevant for

117 lateral boundaries as they are blocked by the impermeable exterior anyway, but may lead to a lower

118 effective diffusion coefficient, since the spatial distribution of materials at the top and bottom of the

119 domain do not match, which imposes an additional diffusion barrier. The reduction by this discontinuity

120 was in the range of $5.110^{-9}$ to $6.710^{-8} \mathrm{~m}^{2} \mathrm{~s}^{-1}$ in small test images (500

121 saturations. 


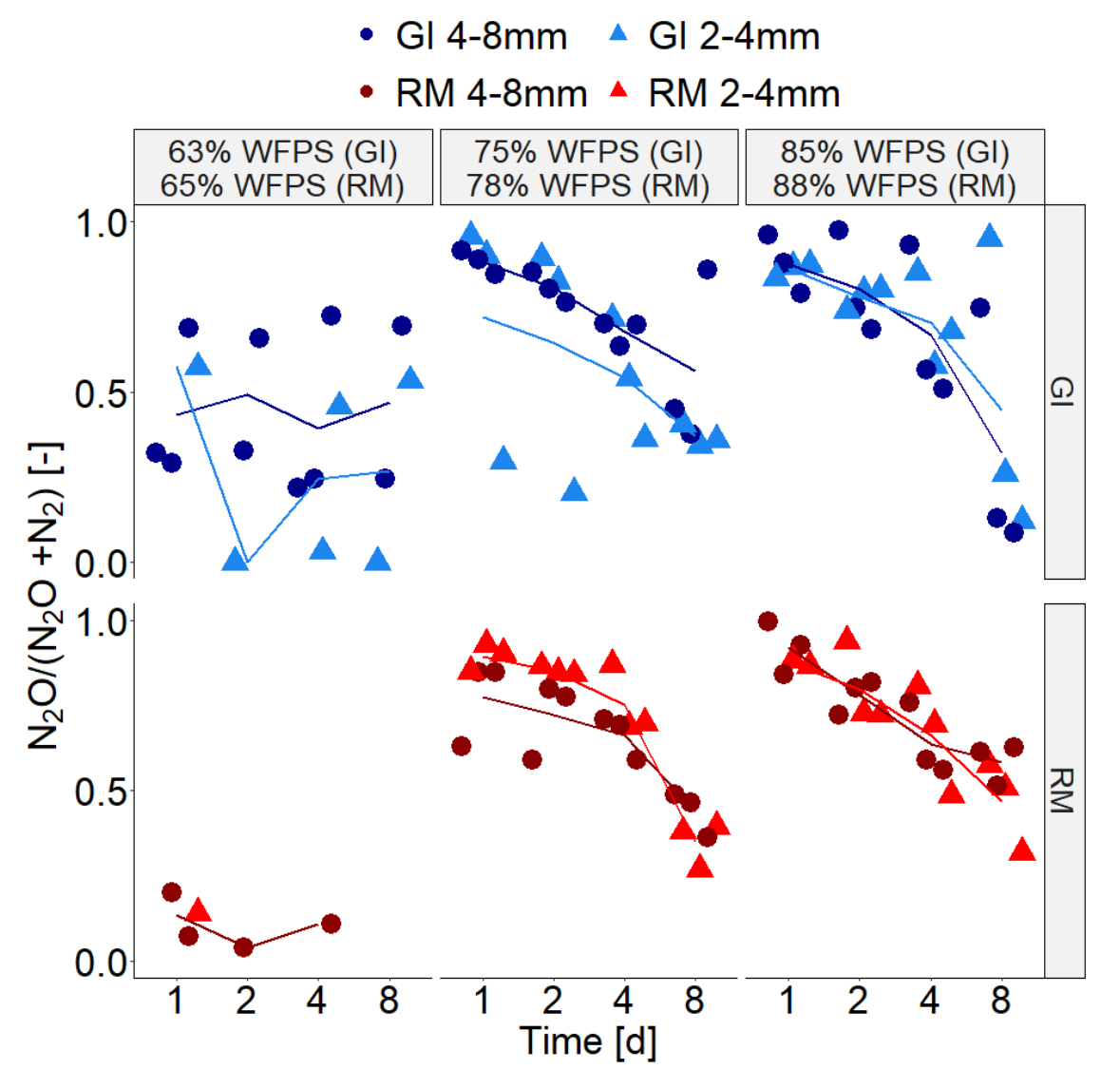

Figure S5: Product ratio $(p r)\left[\mathrm{N}_{2} \mathrm{O} /\left(\mathrm{N}_{2} \mathrm{O}+\mathrm{N}_{2}\right)\right]$ as a function of time for soil from Gießen (GI) in blue and Rotthalmünster

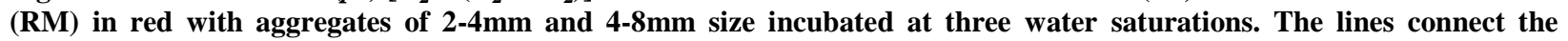
average values of three replicates (large and small aggregates, respectively). 


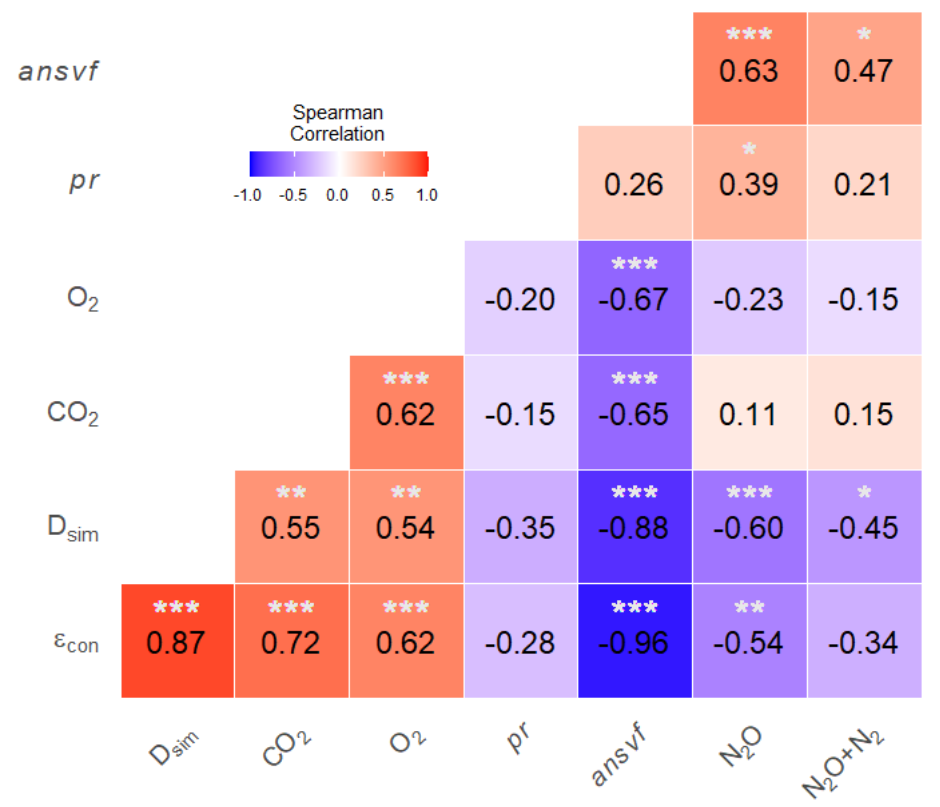

Figure S6: Correlation matrix of Spearman's rank correlation showing coefficients $(R)$ between two measured variables $\left(\mathrm{N}_{2} \mathrm{O},\left(\mathrm{N}_{2} \mathrm{O}+\mathrm{N}_{2}\right)\right.$ or $\mathrm{CO}_{2}$ fluxes, anaerobic soil volume fraction (ansvf), product ratio $(\mathrm{pr}), \mathrm{O}_{2}$ saturation $\left(\mathrm{O}_{2}\right)$, simulated diffusivity $\left(D_{\text {sim }}\right)$ or connected air content $\left.\left(\varepsilon_{c o n}\right)\right)$ in one cell with pairwise deletion of missing values. Asterisks indicate the statistical significance with significance levels of $* \mathrm{p} \leq 0.05, * * \mathbf{p} \leq \mathbf{0 . 0 0 5}, * * * \mathrm{p} \leq \mathbf{0 . 0 0 1}$ for adjusted $\mathbf{p}$-values according to the method of Benjamini and Hochberg (1995). Color scheme indicate low (light colors) or strong (intensive colors) correlation as well as positive (red) or negative (blue) correlation. 

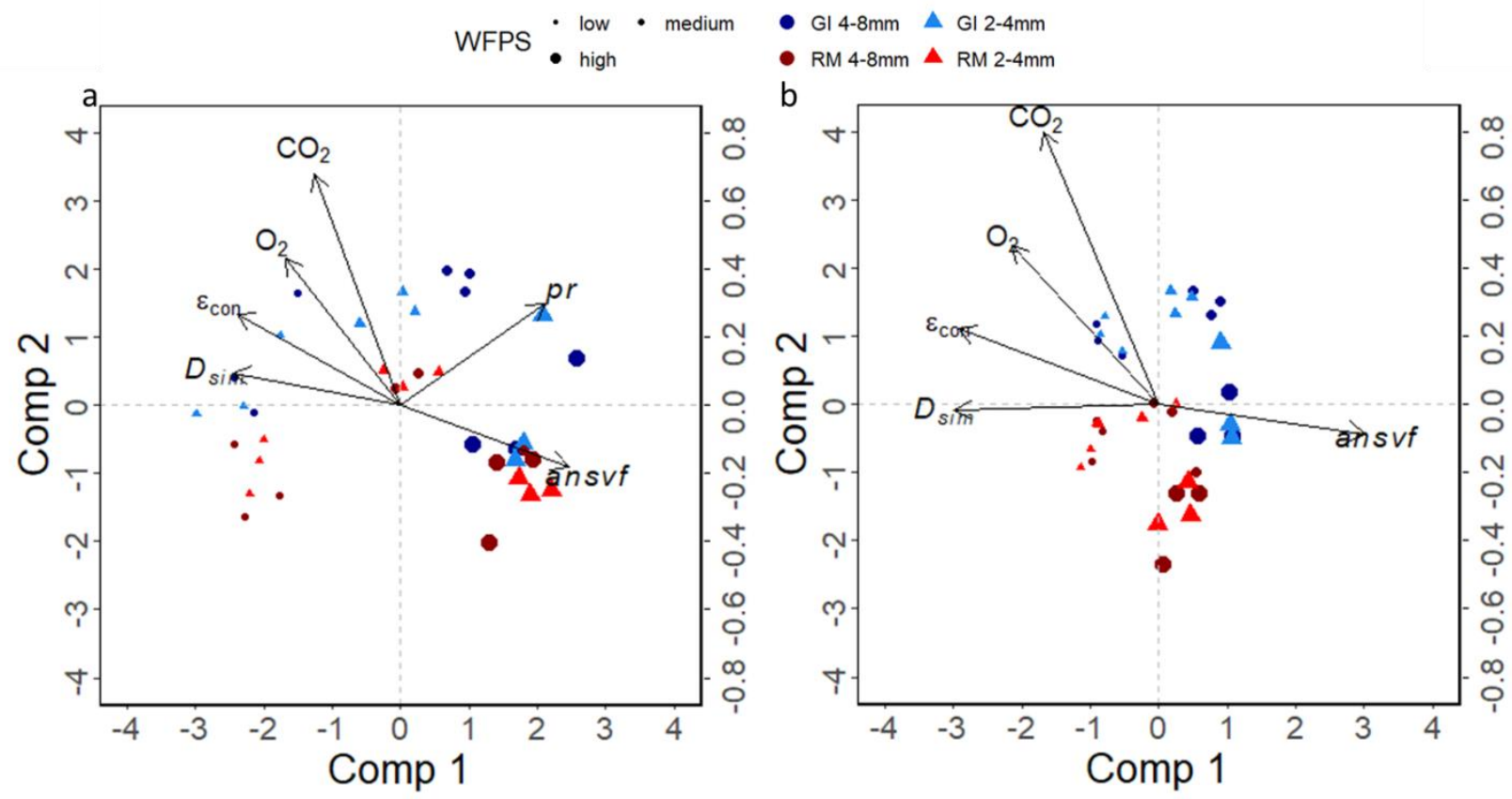

Figure S7: Biplot of the PLSR results for response variables $\mathrm{N}_{2} \mathrm{O}$ (a) and $\left(\mathrm{N}_{2} \mathrm{O}+\mathrm{N}_{2}\right)$ fluxes (b) showing $\mathrm{x}$-scores and $\mathrm{x}$ loadings of two components (Comp 1 and Comp2). The $x$ - and $y$ - axis represent values of the scores for soil from Gießen (GI) in blue and Rotthalmünster (RM) in red with aggregates of $2-4 \mathrm{~mm}$ (triangles) and 4-8mm size (circles) incubated at three water saturations depicted by the size of symbols. The second $y$-axis represents values for the loadings (predictors and arrows) to show the influence of variables on the components.

The regression equations with $\mathrm{R}^{2}$ values and a confidence interval of $95 \%$ in square brackets resulting from PLSR with $\mathrm{CO}_{2},(p r)$ and ansvf as explanatory variables to predict $\mathrm{N}_{2} \mathrm{O}$ or $\left(\mathrm{N}_{2} \mathrm{O}+\mathrm{N}_{2}\right)$ fluxes of the present study for data after log- or logit transformation:

$\log \left(N_{2} O\right)=$

$$
0.17 \log \left(\mathrm{CO}_{2}\right)+0.08 \operatorname{logit}(\operatorname{ansvf})+0.13 p r-0.08 \log \left(D_{\text {sim }}\right)-
$$

$$
0.03 \text { connected air content }+0.03 O_{2} ; \mathrm{R}^{2}=0.71[0.51-0.84]
$$

$\log \left(N_{2} O+N_{2}\right)=$

$$
0.33 \log \left(\mathrm{CO}_{2}\right)+0.18 \operatorname{logit}(\operatorname{ansvf})-0.18 \log \left(D_{\text {sim }}\right)-
$$

$$
0.10 \text { connected air content }+0.05 O_{2} ; \mathrm{R}^{2}=0.79[0.64-0.89]
$$

The regression equations with $\mathrm{R}^{2}$ values and a confidence interval of $95 \%$ in square brackets resulting from PLSR with $\mathrm{CO}_{2}$, ansvf (and pr) identified as most important explanatory variables to predict $\mathrm{N}_{2} \mathrm{O}$ or $\left(\mathrm{N}_{2} \mathrm{O}+\mathrm{N}_{2}\right)$ fluxes of the present study for data after log- or logit transformation:

$$
\log \left(\mathrm{N}_{2} \mathrm{O}\right)=0.18 \log \left(\mathrm{CO}_{2}\right)+0.14 \operatorname{logit}(\text { ansvf })+0.15 p r ; \mathrm{R}^{2}=0.71[0.55-0.83]
$$

$$
\log \left(\mathrm{N}_{2} \mathrm{O}+\mathrm{N}_{2}\right)=0.35 \log \left(\mathrm{CO}_{2}\right)+0.42 \operatorname{logit}(\text { ansvf }) ; \mathrm{R}^{2}=0.83[0.71-0.90]
$$


It is assumed, that the total porosity $[\Phi]$ was unaffected by the packing procedure, whereas the air content $(\varepsilon)$ is expected to differ from the theoretic value due to compact regions and intervals caused by

162 the packing (Figure S4). Following from this, the target bulk density of the repacked soil cores was used

163 to calculate $\Phi$ ( 0.62 or 0.51 for GI and RM soil, respectively), while CT-derived $\varepsilon$ was used. This enabled

164 to calculate diffusivity based on the frequently used model of Millington and Quirk (1960), Millington

165 and Quirk (1961), Moldrup et al. (2000) and also according to the model of Deepagoda et al. (2011)

166 (Figure S6). As expected, diffusivity from these models has a lower explanatory power for $\mathrm{N}_{2} \mathrm{O}$ and

$167 \quad\left(\mathrm{~N}_{2} \mathrm{O}+\mathrm{N}_{2}\right)$ release compared to $D_{\text {sim }}$ of the present study (3D simulation) (Table S2). Higher diffusivities

168 for treatments $\geq 75 \%$ WFPS from empirical models $\left(D_{\text {emp }}\right)$ compared to $D_{\text {sim }}$ result from heterogeneities in

169 compaction of the repacked soil core as described earlier (Figure S8, Figure S4), while empirical models

170 were developed for natural soils that very likely possess higher air continuity at low air content. These

171 empirical models only take averages for porosity and water-filled pores into account (Millington and

172 Quirk, 1961; Moldrup et al., 2000) (Figure S8, Table S2), whereas heterogeneities in compaction are

173 explicitly considered in 3D diffusivity simulations $\left(D_{\text {sim }}\right)$.

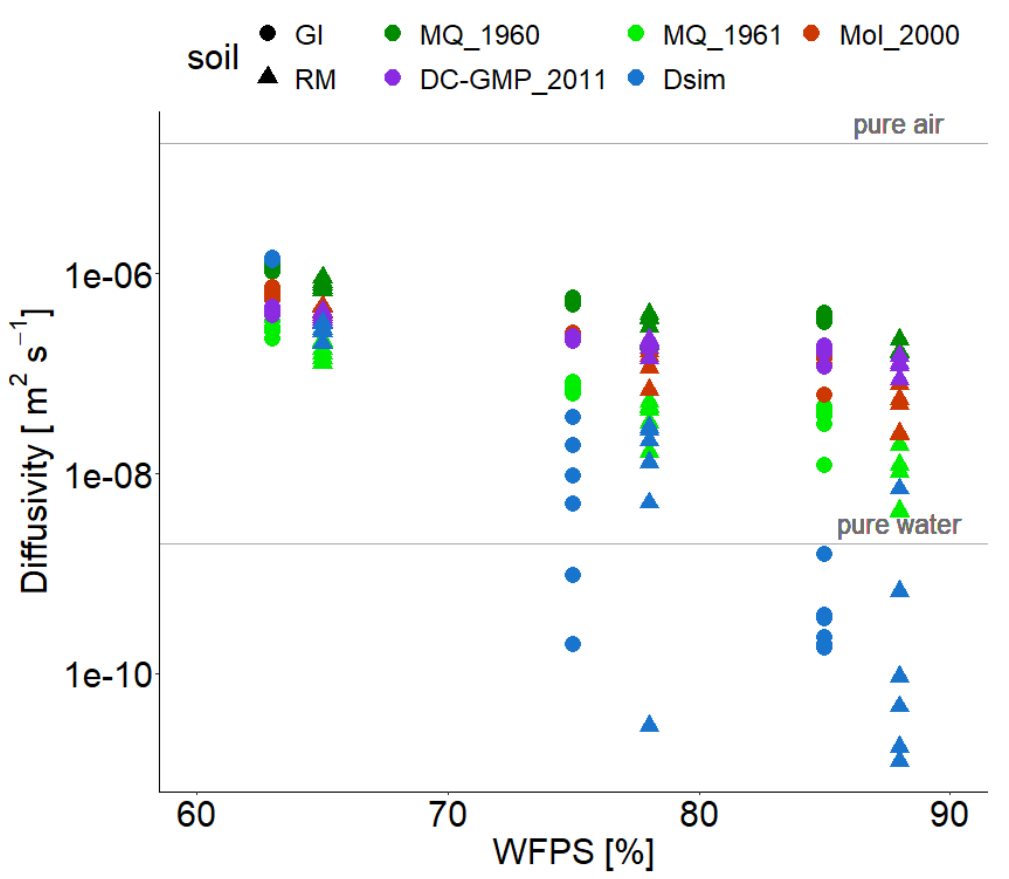

Figure S8: Simulated diffusivities $\left(D_{\text {sim }}\right)$ of the present study and calculated diffusivities as a function of WFPS for both soils (RM and GI). Models used to calculate diffusivity are published by Millington and Quirk (1960) (MQ_1960), Millington and Quirk (1961) (MQ_1961), Moldrup et al. (2000) (Mol_2000) and Deepagoda et al. (2011) (DC_GMP_2011). According to the calculations of the present study diffusivity in free air $\left(D_{0}\right)$ was assumed to be $2.0310^{-5} \mathrm{~m}^{2} \mathrm{~s}^{-1}$. 
Table S2: Explained variability (expressed as $\mathbf{R}^{2}$ ) with confidence interval of $95 \%$ in square brackets for $\mathrm{N}_{2} \mathrm{O}$ and $\left(\mathrm{N}_{2} \mathrm{O}+\mathrm{N}_{2}\right)$ release obtained from partial least square regression (PLSR) using explanatory variables $\mathrm{CO}_{2}$, diffusivity (and product ratio ( $p r)$ for $\mathrm{N}_{2} \mathrm{O}$ as response variable only). This was done to assess possibilities to substitute one of the most important explanatory variables (ansvf) by diffusivity. Data were pooled for both soils (RM and GI), WFPS treatments and aggregate sizes $(n=36)$. Diffusivity was obtained by 3D simulation of the present study $\left(D_{\text {sim }}\right)$ or existing soil gas diffusivity models were used to calculate diffusivity, using total porosity $(\Phi)$ and air content $(\varepsilon)$ while diffusivity in free air $\left(D_{0}\right)$ is assumed to be $2.0310^{-5} \mathrm{~m}^{2} \mathrm{~s}^{-1}$.

\begin{tabular}{|c|c|c|c|}
\hline method & $\begin{array}{l}\text { Equation to calculate } \\
\text { diffusivity } D_{p}\left[\mathrm{~m}^{2} \mathrm{~s}^{-1}\right]\end{array}$ & $\begin{array}{c}\mathrm{R}^{2} \text { with response } \\
\text { variable } \mathrm{N}_{2} \mathrm{O}\end{array}$ & $\begin{array}{c}\mathrm{R}^{2} \text { with response } \\
\text { variable }\left(\mathrm{N}_{2} \mathrm{O}+\mathrm{N}_{2}\right)\end{array}$ \\
\hline Present study $^{1}$ & $D_{\text {sim }}$ & $0.50[0.23-0.71]$ & $0.67[0.41-0.80]$ \\
\hline Millington \& Quirk (1961) ${ }^{1}$ & $\left(\varepsilon^{10 / 3} / \Phi^{2}\right) D_{0}$ & $0.39[0.13-0.64]$ & $0.54[0.23-0.72]$ \\
\hline Millington \& Quirk (1960) ${ }^{1}$ & $\left(\varepsilon^{2} / \Phi^{2 / 3}\right) D_{0}$ & $0.38[0.11-0.63]$ & $0.50[0.19-0.70]$ \\
\hline Moldrup et al. $(2000)^{1}$ & $\varepsilon^{1.5}(\varepsilon / \Phi) \mathrm{D}_{0}$ & $0.50[0.20-0.71]$ & $0.51[0.20-0.72]$ \\
\hline Deepagoda et al $(2011)^{1}$ & $0.1\left[2(\varepsilon / \Phi)^{3}+0.04(\varepsilon / \Phi)\right] \mathrm{D}_{0}$ & $0.42[0.10-0.66]$ & $0.64[0.40-0.79]$ \\
\hline theoretic air content ${ }^{2}$ & $\varepsilon_{t}$ & $0.45[0.20-0.68]$ & $0.76[0.57-0.86]$ \\
\hline no diffusivity ${ }^{3}$ & - & $0.42[0.10-0.67]$ & 0.06 \\
\hline
\end{tabular}

${ }^{1}$ PLSR with $\mathrm{CO}_{2}$ and diffusivity (and product ratio $(p r)$ ) as explanatory variables and $\mathrm{N}_{2} \mathrm{O}$ or $\left(\mathrm{N}_{2} \mathrm{O}+\mathrm{N}_{2}\right)$ as response variables.

${ }^{2}$ Diffusivity substituted by the theoretic air content $\left(\varepsilon_{t}\right)$ targeted during packing in PLSR.

${ }^{3}$ Diffusivity was excluded in PLSR resulting in $\mathrm{CO}_{2}$ (and product ratio (pr)) as explanatory variable for $\mathrm{N}_{2} \mathrm{O}$ and for $\left(\mathrm{N}_{2} \mathrm{O}+\mathrm{N}_{2}\right)$. Because $\mathrm{CO}_{2}$ was the single explanatory variable for $\left(\mathrm{N}_{2} \mathrm{O}+\mathrm{N}_{2}\right)$ a simple linear model was used to estimate $\mathbf{R}^{2}$.

\section{Calculation of anaerobic soil volume fraction (ansvf) by $\left(\mathrm{N}_{2} \mathrm{O}+\mathrm{N}_{2}\right)$ fluxes from oxic and anoxic} incubations

To calculate an anaerobic soil volume fraction within the soil cores $\left(a n s v f_{c a l}\right)$ independently from the X-ray CT imaging derived ansvf, parallel anoxic incubations were conducted to the described oxic incubations using a different suite of larger repacked soil cores. The conditions for incubations were very similar in soil cores as described before (in the Methods section and Supplementary Material) for oxic incubation. Deviations from the experimental protocol were the dimension of the soil core $(10 \times 14.4 \mathrm{~cm})$, unspecific sieving $(>10 \mathrm{~mm})$, a flow rate of $20 \mathrm{~mL} / \mathrm{min}$ and a target saturation of $75 \%$ WFPS for both soils (GI and RM). Soil material was obtained from the same batches that had been used for the oxic incubations. Batches consisted of approx. 2000kg sieved, homogenized and air-dried soil stored at $6^{\circ} \mathrm{C}$ that had been collected and prepared to allow the study of comparable soil samples in various labs during several years. After one week with oxic incubation using a technical gas $\left(20 \% \mathrm{O}_{2}\right.$ and $2 \% \mathrm{~N}_{2}$ in pure $\left.\mathrm{He}\right)$ the atmospheric conditions were switched to anoxic conditions $\left(2 \% \mathrm{~N}_{2}\right.$ in pure $\left.\mathrm{He}\right) . \mathrm{N}_{2} \mathrm{O}$ and $\mathrm{N}_{2}$ fluxes were quantified using the ${ }^{15} \mathrm{~N}$ labelling approach as described before. A comparison of oxic and anoxic $\left(\mathrm{N}_{2} \mathrm{O}+\mathrm{N}_{2}\right)$ fluxes under these comparable conditions is possible because ansvf $f_{c a l}$ assumes that actual denitrification is linearly related to ansvf and that the specific anoxic denitrification rate is homogenous, i.e. would be identical at any location within the soil. 
The calculated ansvf $\left(\right.$ ansvf $\left.f_{\text {cal }}\right)$ derived from incubation $\left(\mathrm{N}_{2} \mathrm{O}+\mathrm{N}_{2}\right)$ fluxes with oxic $\left(\left(\mathrm{N}_{2} \mathrm{O}+\mathrm{N}_{2}\right)_{\text {oxic }}\right)$ and

211 anoxic $\left(\left(\mathrm{N}_{2} \mathrm{O}+\mathrm{N}_{2}\right)_{\text {anoxic }}\right)$ conditions is thus (Table S3):

$212 \quad a n s v f_{\text {cal }}=\frac{\left(\mathrm{N}_{2} \mathrm{O}+\mathrm{N}_{2}\right)_{\text {oxic }}}{\left(\mathrm{N}_{2} \mathrm{O}+\mathrm{N}_{2}\right)_{\text {anoxic }}}$

213

Table S3: Average $\left(\mathrm{N}_{2} \mathrm{O}+\mathrm{N}_{2}\right)$ fluxes with oxic conditions $\left(\left(\mathrm{N}_{2} \mathrm{O}+\mathrm{N}_{2}\right)_{\text {oxic }}\right.$, present study; $\left.\mathrm{n}=3\right)$ and with anoxic conditions $\left(\left(\mathrm{N}_{2} \mathrm{O}+\mathrm{N}_{2}\right)_{\text {anoxic }}\right.$, parallel incubations, $\left.\mathrm{n}=4\right)$ for soils from Rotthalmünster (RM) and Gießen (GI). Oxic incubations were conducted with two aggregate sizes $(2-4$ and $4-8 \mathrm{~mm})$ at $75 \%$ WFPS (GI) or $78 \%$ WFPS (RM). Anoxic conditions were established after 7 days of oxic incubation. Average $\left(\mathrm{N}_{2} \mathrm{O}+\mathrm{N}_{2}\right)$ fluxes from oxic and anoxic incubations served to calculate the anaerobic soil volume fraction $\left(\right.$ ans $\left.v f_{c a l}\right)$. In comparison to the ansvf $f_{\text {cal }}$, ansvf derived from $\mathrm{X}$-Ray CT imaging ansv $f_{c a l}$ result from the present study is also presented

\begin{tabular}{|c|c|c|c|c|c|c|}
\hline soil & WFPS & $\begin{array}{c}\text { Aggregate size } \\
{[\mathrm{mm}]}\end{array}$ & $\begin{array}{c}\left(\mathrm{N}_{2} \mathrm{O}+\mathrm{N}_{2}\right)_{\text {oxic }} \\
{\left[\mu \mathrm{N} \mathrm{h}^{-1} \mathrm{~kg}^{-1}\right]} \\
(\text { present study) }\end{array}$ & $\begin{array}{c}\left(\mathrm{N}_{2} \mathrm{O}+\mathrm{N}_{2}\right)_{\text {anoxic }} \\
{\left[\mu \mathrm{N} \mathrm{h}^{-1} \mathrm{~kg}^{-1}\right]} \\
\text { (parallel incubation) }\end{array}$ & $\begin{array}{c}\text { ansvf } \\
\text { ansvf cal }\end{array}$ & (present study) \\
\hline RM & $75-78$ & $2-8$ & 0.37 & 1.84 & 0.20 & 0.21 \\
\hline GI & 75 & $2-8$ & 1.37 & 3.60 & 0.38 & 0.13 \\
\hline
\end{tabular}


Table with data for each replicate with average values of $\mathrm{CO}_{2}, \mathrm{~N}_{2} \mathrm{O}$ and $\left(\mathrm{N}_{2} \mathrm{O}+\mathrm{N}_{2}\right)$ fluxes, $\mathrm{O}_{2}$ saturation, total porosity, visible air content, connected air content $\left(\varepsilon_{\text {con }}\right)$, anaerobic soil volume fraction (ansvf), diffusivity $\left(D_{\text {sim }}\right)$ and product ratio (pr)

Table S4: Average values of $\mathrm{CO}_{2}, \mathrm{~N}_{2} \mathrm{O}$ and $\left(\mathrm{N}_{2} \mathrm{O}+\mathrm{N}_{2}\right)$ fluxes, $\mathrm{O}_{2}$ saturation, total porosity, visible air content ( $\left.\varepsilon_{v i s}\right)$, connected air content $\left(\varepsilon_{\text {con }}\right)$, anaerobic soil volume fraction (ansvf), diffusivity and product ratio $\left[\mathrm{N}_{2} \mathrm{O} /\left(\mathrm{N}_{2} \mathrm{O}+\mathrm{N}_{2}\right)\right]$ for the two soils (Gießen (GI) and Rotthalmünster (RM)), three water saturations and two aggregate sizes 224 for three replicates. Standard error of the mean is shown in the brackets.

\begin{tabular}{|c|c|c|c|c|c|c|c|c|c|c|c|c|c|}
\hline soil & $\begin{array}{c}\text { WF } \\
\text { PS[ } \\
\%]\end{array}$ & $\begin{array}{c}\text { Aggre- } \\
\text { gate size } \\
{[\mathrm{mm}]}\end{array}$ & $\begin{array}{c}\text { Rep } \\
\text { li- } \\
\text { cate }\end{array}$ & $\begin{array}{c}\mathrm{CO}_{2}-\mathrm{C} \\
{\left[\mu \mathrm{g} \mathrm{h}^{-1} \mathrm{~kg}^{-1}\right]} \\
(\mathrm{n}=28)\end{array}$ & $\begin{array}{c}\mathrm{N}_{2} \mathrm{O}-\mathrm{N} \\
{\left[\mu \mathrm{g} \mathrm{h}^{-1} \mathrm{~kg}^{-1}\right]} \\
(\mathrm{n}=28)\end{array}$ & $\begin{array}{c}\left(\mathrm{N}_{2} \mathrm{O}+\mathrm{N}_{2}\right) \\
{\left[\mu \mathrm{g} \mathbf{~ h}^{-1} \mathrm{~kg}^{-}\right.} \\
\left.{ }_{1}\right](\mathrm{n}=3)\end{array}$ & $\begin{array}{c}\mathrm{O}_{2}[\% \text { air } \\
\text { saturation] } \\
(\mathrm{n}=7)\end{array}$ & $\begin{array}{c}\text { Total } \\
\text { poro- } \\
\text { sity [-] }\end{array}$ & $\begin{array}{l}\varepsilon_{v i s} \\
{[-]}\end{array}$ & $\begin{array}{l}\varepsilon_{\text {con }} \\
{[-]}\end{array}$ & $\begin{array}{c}\text { ansvf } \\
{[-]}\end{array}$ & $\underset{\left.\mathbf{s}^{-2}\right]}{D_{\text {sim }}}\left[\mathbf{m}^{2}\right.$ & $\begin{array}{c}p r \\
(n=1-3)\end{array}$ \\
\hline GI & 63 & $2-4$ & $\mathrm{a}$ & $17.85(0.14)$ & $0.01(<0.01)$ & NA & $47.19(12.13)$ & 0.20 & 0.20 & 0.19 & 0.003 & $1.1010^{-06}$ & n.d. \\
\hline GI & 63 & $4-8$ & $\mathrm{a}$ & $17.02(0.12)$ & $0.02(<0.01)$ & 0.10 & $53.79(13.07)$ & 0.19 & 0.19 & 0.19 & 0.004 & $1.0510^{-06}$ & 0.22 (n.d) \\
\hline GI & 75 & $2-4$ & $\mathrm{a}$ & $23.23(0.16)$ & $0.94(0.04)$ & $1.39(0.34)$ & $46.27(11.64)$ & 0.18 & 0.13 & 0.12 & 0.037 & $2.8910^{-08}$ & $0.68(0.14)$ \\
\hline GI & 75 & $4-8$ & $\mathrm{a}$ & $20.35(0.15)$ & $0.89(0.03)$ & $1.33(0.26)$ & $59.24(11.59)$ & 0.19 & 0.14 & 0.10 & 0.246 & $7.5010^{-10}$ & $0.67(0.12)$ \\
\hline GI & 85 & $2-4$ & $\mathrm{a}$ & $13.95(0.11)$ & $1.48(0.03)$ & $1.75(0.17)$ & $39.43(9.42)$ & 0.17 & 0.11 & 0.07 & 0.513 & $1.5410^{-10}$ & $0.85(0.06)$ \\
\hline GI & 85 & $4-8$ & $\mathrm{a}$ & $7.39(0.10)$ & $0.97(0.03)$ & $1.10(0.12)$ & $39.66(12.20)$ & 0.18 & 0.08 & 0.02 & 0.824 & $1.4010^{-10}$ & $0.88(0.07)$ \\
\hline GI & 63 & $2-4$ & $\mathrm{~b}$ & $23.81(0.37)$ & $<0.01(<0.01)$ & 0.22 (NA) & $45.32(10.48)$ & 0.22 & 0.22 & 0.21 & 0.001 & $1.1110^{-06}$ & 0.03 (n.d.) \\
\hline GI & 63 & $4-8$ & $\mathrm{~b}$ & $22.24(0.32)$ & $0.03(<0.01)$ & $0.11(0.01)$ & $57.38(11.56)$ & 0.21 & 0.21 & 0.21 & 0.001 & $1.1110^{-06}$ & $0.27(0.03)$ \\
\hline GI & 75 & $2-4$ & $\mathrm{~b}$ & $26.83(0.22)$ & $0.91(0.04)$ & $1.60(0.46)$ & $62.33(6.19)$ & 0.18 & 0.13 & 0.12 & 0.068 & $1.4910^{-08}$ & $0.57(0.14)$ \\
\hline GI & 75 & $4-8$ & $\mathrm{~b}$ & $23.07(0.20)$ & $0.86(0.04)$ & $1.42(0.34)$ & $71.78(7.66)$ & 0.19 & 0.14 & 0.10 & 0.312 & $1.5210^{-10}$ & $0.60(0.12)$ \\
\hline GI & 85 & $2-4$ & $\mathrm{~b}$ & $4.19(0.13)$ & $0.55(0.02)$ & $1.01(0.31)$ & $28.45(10.02)$ & 0.18 & 0.12 & $<0.01$ & 0.935 & $1.2310^{-09}$ & $0.54(0.15)$ \\
\hline GI & 85 & $4-8$ & $\mathrm{~b}$ & $4.26(0.12)$ & $0.44(0.03)$ & $0.91(0.40)$ & $34.16(9.45)$ & 0.18 & 0.11 & $<0.01$ & 0.938 & $1.8210^{-10}$ & $0.48(0.18)$ \\
\hline GI & 63 & $2-4$ & $\mathrm{c}$ & $28.94(0.24)$ & $0.02(0.04)$ & $0.04(<0.01)$ & $51.43(9.55)$ & 0.21 & 0.21 & 0.20 & $<0.001$ & $1.0510^{-06}$ & $0.50(0.04)$ \\
\hline GI & 63 & $4-8$ & $\mathrm{c}$ & $27.05(0.20)$ & $0.12(0.04)$ & $0.17(0.04)$ & $70.19(6.95)$ & 0.20 & 0.20 & 0.20 & $<0.001$ & $1.0810^{-06}$ & $0.69(0.02)$ \\
\hline GI & 75 & $2-4$ & $\mathrm{c}$ & $31.29(0.23)$ & $0.53(0.04)$ & $1.70(0.48)$ & $60.83(8.62)$ & 0.19 & 0.13 & 0.13 & 0.018 & $3.8810^{-09}$ & $0.31(0.05)$ \\
\hline GI & 75 & $4-8$ & $\mathrm{c}$ & $28.88(0.26)$ & $0.62(0.05)$ & $0.80(0.19)$ & $54.30(14.00)$ & 0.19 & 0.14 & 0.13 & 0.063 & $7.3810^{-09}$ & $0.77(0.05)$ \\
\hline GI & 85 & $2-4$ & $\mathrm{c}$ & $4.96(0.33)$ & $0.44(0.05)$ & $0.83(0.44)$ & $23.67(10.43)$ & 0.18 & 0.12 & $<0.01$ & 0.910 & $2.9810^{-10}$ & $0.53(0.21)$ \\
\hline GI & 85 & $4-8$ & $\mathrm{c}$ & $4.90(0.29)$ & $0.34(0.05)$ & $0.80(0.48)$ & $45.84(10.25)$ & 0.23 & 0.12 & 0.02 & 0.629 & $2.7510^{-10}$ & $0.43(0.18)$ \\
\hline $\mathrm{RM}$ & 65 & $2-4$ & $\mathrm{a}$ & $6.06(0.03)$ & $<0.01(<0.01)$ & $\mathrm{NA}$ & $68.61(7.14)$ & 0.15 & 0.15 & 0.14 & 0.004 & $2.5110^{-07}$ & n.d. \\
\hline RM & 65 & $4-8$ & $\mathrm{a}$ & $7.22(0.04)$ & $<0.01(<0.01)$ & NA & $35.75(12.64)$ & 0.16 & 0.16 & 0.15 & 0.005 & $2.4710^{-07}$ & n.d. \\
\hline RM & 78 & $2-4$ & $\mathrm{a}$ & $7.95(0.07)$ & $<0.01(<0.01)$ & $0.01(<0.01)$ & $63.18(10.22)$ & 0.14 & 0.11 & 0.10 & 0.004 & $1.6610^{-08}$ & $0.71(0.16)$ \\
\hline $\mathrm{RM}$ & 78 & $4-8$ & $\mathrm{a}$ & $3.12(0.04)$ & $0.16(<0.01)$ & $0.27(0.06)$ & $43.27(11.97)$ & 0.14 & 0.08 & 0.03 & 0.775 & $2.3410^{-11}$ & $0.60(0.06)$ \\
\hline RM & 88 & $2-4$ & $\mathrm{a}$ & $1.89(<0.01)$ & $0.14(<0.01)$ & $0.18(0.03)$ & $12.13(8.11)$ & 0.10 & 0.07 & 0.05 & 0.502 & $7.3110^{-11}$ & $0.78(0.11)$ \\
\hline RM & 88 & $4-8$ & $\mathrm{a}$ & $1.15(<0.01)$ & $0.15(<0.01)$ & $0.21(0.02)$ & $38.36(11.27)$ & 0.10 & 0.05 & 0.02 & 0.753 & $5.5310^{-09}$ & $0.70(0.04)$ \\
\hline RM & 65 & $2-4$ & $\mathrm{~b}$ & $4.98(0.33)$ & $<0.01(<0.01)$ & NA & $48.38(11.00)$ & 0.17 & 0.17 & 0.16 & 0.003 & $2.1010^{-07}$ & n.d. \\
\hline $\mathrm{RM}$ & 65 & $4-8$ & $\mathrm{~b}$ & $5.22(0.37)$ & $<0.01(<0.01)$ & 0.06 & $42.40(11.85)$ & 0.15 & 0.15 & 0.14 & 0.005 & $1.5710^{-07}$ & 0.04 (n.d.) \\
\hline $\mathrm{RM}$ & 78 & $2-4$ & $\mathrm{~b}$ & $7.32(0.09)$ & $0.27(<0.01)$ & $0.45(0.15)$ & $56.52(8.62)$ & 0.13 & 0.10 & 0.08 & 0.042 & $1.0210^{-08}$ & $0.60(0.17)$ \\
\hline $\mathrm{RM}$ & 78 & $4-8$ & $\mathrm{~b}$ & $7.17(0.04)$ & $0.32(<0.01)$ & $0.49(0.09)$ & $69.43(9.15)$ & 0.14 & 0.11 & 0.09 & 0.193 & $2.1310^{-08}$ & $0.65(0.10)$ \\
\hline RM & 88 & $2-4$ & $\mathrm{~b}$ & $1.89(<0.01)$ & $0.24(<0.01)$ & $0.37(0.04)$ & $28.13(9.56)$ & 0.09 & 0.07 & 0.01 & 0.856 & $1.0410^{-11}$ & $0.64(0.07)$ \\
\hline RM & 88 & $4-8$ & $\mathrm{~b}$ & $2.42(0.03)$ & $0.31(<0.01)$ & $0.50(0.08)$ & $46.26(9.60)$ & 0.14 & 0.07 & 0.01 & 0.860 & $3.6510^{-11}$ & $0.63(0.09)$ \\
\hline
\end{tabular}




\begin{tabular}{|c|c|c|c|c|c|c|c|c|c|c|c|c|c|}
\hline $\mathrm{RM}$ & 65 & $2-4$ & $\mathrm{c}$ & $8.05(0.03)$ & n.d. & NA & $53.25(14.68)$ & 0.17 & 0.17 & 0.16 & 0.003 & $2.1010^{-07}$ & n.d. \\
\hline RM & 65 & $4-8$ & $\mathrm{c}$ & $8.39(0.04)$ & n.d. & NA & $68.71(15.40)$ & 0.16 & 0.16 & 0.15 & 0.003 & $2.1910^{-07}$ & 0.11 (n.d.) \\
\hline RM & 78 & $2-4$ & $\mathrm{c}$ & $7.70(0.01)$ & $0.29(<0.01)$ & $0.44(0.10)$ & $57.79(6.92)$ & 0.14 & 0.11 & 0.08 & 0.203 & $4.0010^{-09}$ & $0.64(0.13)$ \\
\hline RM & 78 & $4-8$ & $\mathrm{c}$ & $8.51(0.06)$ & $0.31(0.02)$ & $0.54(0.16)$ & $58.57(12.57)$ & 0.14 & 0.11 & 0.10 & 0.062 & $2.2810^{-08}$ & $0.57(0.12)$ \\
\hline $\mathrm{RM}$ & 88 & $2-4$ & $\mathrm{c}$ & $2.88(0.02)$ & $0.29(<0.01)$ & $0.56(0.13)$ & $27.69(8.80)$ & 0.11 & 0.05 & 0.02 & 0.720 & $1.4510^{-11}$ & $0.51(0.12)$ \\
\hline $\mathrm{RM}$ & 88 & $4-8$ & $\mathrm{c}$ & $2.61(<0.01)$ & $0.28(<0.01)$ & $0.41(0.05)$ & $41.41(9.23)$ & 0.16 & 0.08 & 0.03 & 0.613 & $5.1910^{-10}$ & $0.67(0.08)$ \\
\hline
\end{tabular}

n.d.: not detectable; $\mathrm{NO}$ and $\mathrm{N}_{2}$ concentration was below detection limit for IRMS analysis, thus calculation of $p r$ was impossible. NA: not applicable 
Benjamini, Y., and Hochberg, Y.: Controlling the False Discovery Rate: A Practical and Powerful

228 Approach to Multiple Testing, Journal of the Royal Statistical Society. Series B (Methodological), 57, 229 289-300, 1995.

Deepagoda, T., Moldrup, P., Schjonning, P., de Jonge, L. W., Kawamoto, K., and Komatsu, T.: DensityCorrected Models for Gas Diffusivity and Air Permeability in Unsaturated Soil, Vadose Zone J., 10, 226238, https://doi.org/10.2136/vzj2009.0137, 2011.

Lewicka-Szczebak, D., Well, R., Giesemann, A., Rohe, L., and Wolf, U.: An enhanced technique for automated determination of ${ }^{15} \mathrm{~N}$ signatures of $\mathrm{N}_{2},\left(\mathrm{~N}_{2}+\mathrm{N}_{2} \mathrm{O}\right)$ and $\mathrm{N}_{2} \mathrm{O}$ in gas samples, Rapid Commun. Mass Spec., 27, 1548-1558, https://doi.org/10.1002/rcm.6605, 2013.

Millington, R., and Quirk, J. P.: Permeability of porous solids, Transactions of the Faraday Society, 57, 1200-\&, https://doi.org/10.1039/tf9615701200, 1961.

Millington, R. J., and Quirk, J. M.: Transport in porous media, in: F.A. Van Beren et. al (ed.), Trans. Int. Congr. Soil Sci., 7th, Madison, WI. 14-21 Aug, Elsevier, Amsterdam, 97-106, 1960.

Moldrup, P., Olesen, T., Gamst, J., Schjonning, P., Yamaguchi, T., and Rolston, D. E.: Predicting the gas diffusion coefficient in repacked soil: Water-induced linear reduction model, Soil Sc. Soc. Am. J., 64, 1588-1594, https://doi.org/10.2136/sssaj2000.6451588x, 2000.

Spott, O., Russow, R., Apelt, B., and Stange, C. F.: A ${ }^{15} \mathrm{~N}$-aided artificial atmosphere gas flow technique for online determination of soil $\mathrm{N}_{2}$ release using the zeolite Köstrolith SX6®, Rapid Commun. Mass Spec., 20, 3267-3274, https://doi.org/10.1002/rcm.2722, 2006.

Well, R., Burkart, S., Giesemann, A., Grosz, B., Köster, J. R., and Lewicka-Szczebak, D.: Improvement of the ${ }^{15} \mathrm{~N}$ gas flux method for in situ measurement of soil denitrification and its product stoichiometry, Rapid Commun. Mass Spec., 33, 437-448, https://doi.org/10.1002/rcm.8363, 2019.

Wiegmann, A., and Bube, K. P.: The explicit-jump immersed interface method: Finite difference methods for PDEs with piecewise smooth solutions, SIAM J. Numer. Anal., 37, 827-862,

259 https://doi.org/10.1137/S0036142997328664, 2000. 